Transactions of the American Fisheries Society, vol. 125, no. 2, 1996, pp. 195-202. Online ISSN: 1548-8659

Print ISSN: 0002-8487

http://afs.allenpress.com/perlserv/?request=get-archive\&ct $=1$

http://afs.allenpress.com/archive/1548-8659/125/2/pdf/i1548-8659-125-2-195.pdf DOI: 10.1577/1548-8659(1996)125<0195:COMSIE>2.3.CO;2

(C) American Fisheries Society. 


\title{
Characteristics of Muskellunge Spermatozoa II: Effects of Ions and Osmolality on Sperm Motility
}

\author{
FENG Lin AND KonRAD DABRowsKi' \\ Sihool of Natural Resources, The Ohio Siate University \\ 2021 Coffey Road, Columbus, Ohio 43210, USA
}

\begin{abstract}
We investigated the effects of potassium, sodium, glucose, and calcium concentrations, alone or in combinations. on sperm motility in muskellunge Esox masquinongy. Sperm motility was evaluated by the duration of sperm movement and the initial percentage of motile sperm. The osmolality of diluents rather than the specific ions or nonelectrolyte played a major role in the regulation of sperm motility in muskellunge. Sperm were fully activated $(>80 \%)$ when the concentration was lower than $50 \mathrm{mM}$ of $\mathrm{KCl}$ and $\mathrm{NaCl}$. or $100 \mathrm{mM}$ glucose (all in $30 \mathrm{mM}$ tris-HCl at pH 8.0). A small percent of spermatozoa could be activated at $150 \mathrm{mM} \mathrm{KCl}$ and $\mathrm{NaCl}$. or $300 \mathrm{mM}$ glucose, which were hypertonic to the seminal plasma. The duration of sperm movement was up to $6-7 \mathrm{~min}$ at $12^{\circ} \mathrm{C}$ in a solution of $100 \mathrm{mM}$ glucose or $50 \mathrm{mM} \mathrm{NaCl}$. Spermatozoa had a prolonged duration of movement in patassium solutions, up to $120 \mathrm{~min}$ at $12^{\circ} \mathrm{C}$ in a solution of $100 \mathrm{mM} \mathrm{KCl}$. The prolonged duration of movement might be caused by reactivation of sperm or gradual activation of sperm motility. Calcium had an inhibitory effect on sperm motility in muskellunge, starting at $3 \mathrm{mM} \mathrm{CaCl} 2$ with $30 \mathrm{mM}$ tris- $\mathrm{HCl}$ at $\mathrm{pH} 8.0$. Semen diluted in calciumsupplemented solutions did not disperse well, and the sperm tended to form clumps. The mechanism involved in muskellunge sperm motility control markedly differs from that in salmonids (inhibitory function of $\mathrm{K}^{\prime}$ and activatory role of $\mathrm{Ca}^{2}$ ) and cyprinids (no effect of $\mathrm{Ca}^{2+}$ ).
\end{abstract}

Artificial fertilization of eggs from muskellunge Esox masquinongy has been successfully accomplished in the past (Hasler et al. 1940; Galat 1973) and is currently used in mass propagation of the species (Moore 1991). Information on sperm physiology will aid in perfecting fertilization techniques and reduce the risk of handling muskellunge gametes under hatchery conditions. We reported for the first time some of the physiological and biochemical characteristics of semen and ultrastructure of spermatozoa in muskellunge (Lin et al. 1996). Understanding the regulatory mechanism of sperm motility is essential for implementing chromosome manipulation experiments and may lead to improved fertilization and efficiency of muskellunge propagation.

Sperm of most teleost fishes are quiescent in the semen and initiate their movement after being released into the environment (Billard 1978; Stoss 1983). Sperm motility is one of the most important parameters of sperm quality and is usually expressed in duration of sperm movement and percentage of motile sperm immediately after activation (Redondo-Muller et al. 1991). Changes in osmolality and potassium concentration have been reported as the major factors that initiate sperm motility in cyprinids and salmonids, respectively (Morisawa and Suzuki 1980; Morisawa et al.

\footnotetext{
I To whom correspondence should be addressed.
}

1983a, 1983b; Stoss 1983). Calcium also plays an important role in the regulation of sperm motility (Tanimoto and Morisawa 1988; Okuno and Morisawa 1989; Boitano and Omoto 1992). Calcium can prevent abrupt change in the swimming speed and can increase the duration of sperm movement in trout (Christen et al. 1987). However, only a few reports on physiological characteristics of spermatozoa of escoids are available. Billard (1978) found that a physiological solution of about $0.7 \%$ salinity, compared with freshwater, increased the motility and fertility of sperm in northern pike Esox lucius. Duplinsky (1982) reported the effects of $\mathrm{pH}$ values on sperm motility of northern pike and chain pickerel Esox niger using buffered tap water. In northern pike, duration of sperm movement at $10-13^{\circ} \mathrm{C}$ showed a strong trend of increase with increasing $\mathrm{pH}$ and reached a maximum duration of $67 \mathrm{~s}$ at $\mathrm{pH} 7.9$.

The goal of this study was to investigate the effects of potassium, sodium, glucose, and calcium concentrations, alone or in combination, on sperm motility and thus to understand the regulatory mechanism of sperm motility in muskellunge.

\section{Methods}

Sexually mature male muskellunge (703-909 $\mathrm{mm}$ total length) were captured with trap nets from Clear Fork Reservoir, Ohio, in April 1993 and 1994. Water temperature of the lake at the time of 

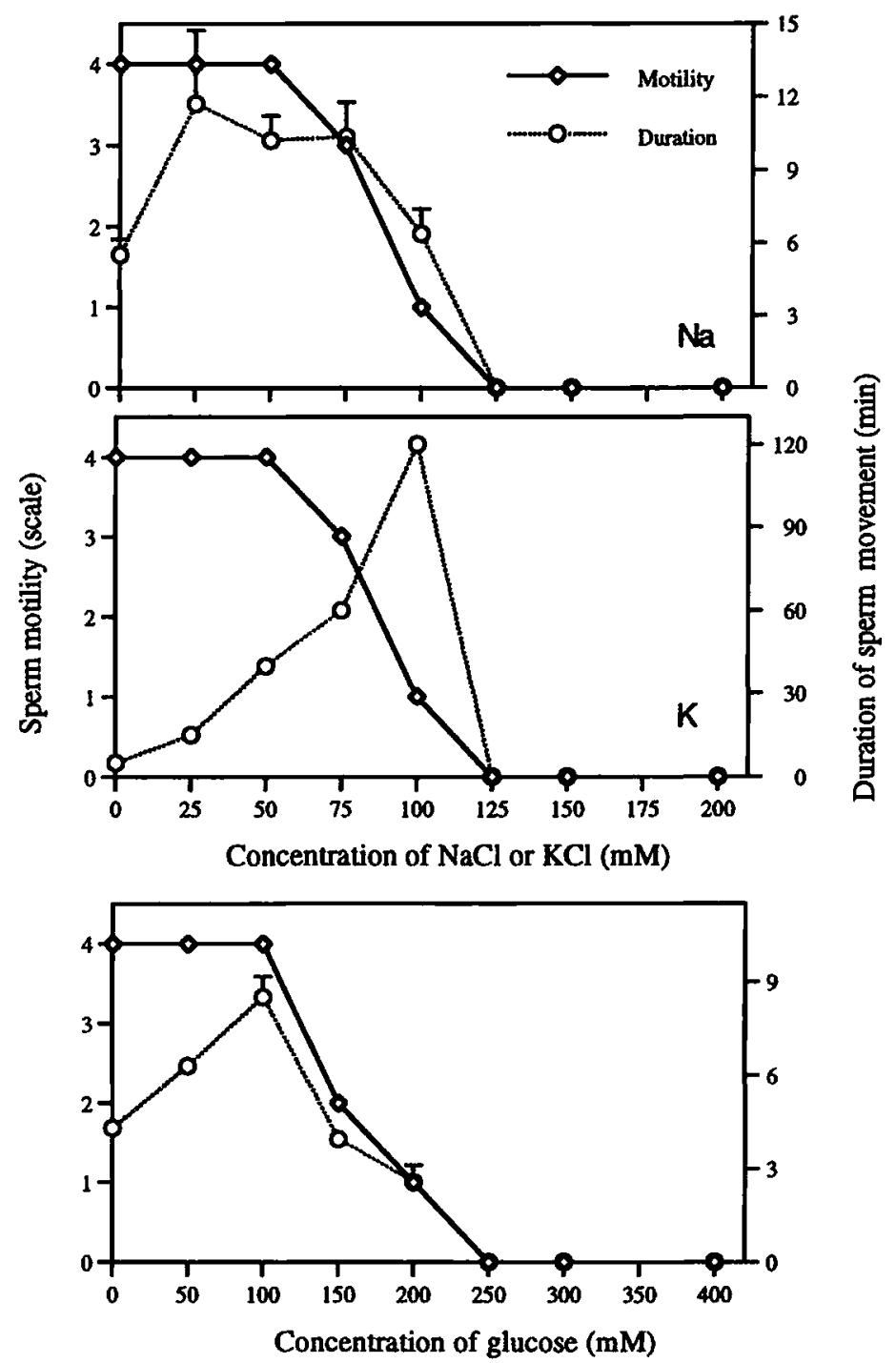

FIGURE 1.-Effects on muskellunge sperm motility of sodium, potassium, and glucose concentrations in the activation solution. Initial percentage of motile sperm (scale, 1993; \%, 1994) was estimated at 5-7 s after activation. The arbitrary scale used in 1993 was defined as $4=75-100 \%, 3=50-75 \%, 2=25-50 \%, 1=0-25 \%, 0=0 \%$. Duration of sperm movement is the time interval from dilution of semen to the time that all sperm ceased their forward movement. For activation, I $\mu \mathrm{L}$ of semen was added to $0.2 \mathrm{~mL}$ of diluent containing various $\mathrm{NaCl}, \mathrm{KCl}$, or glucose concentrations in $30 \mathrm{mM}$ tris $-\mathrm{HCl}$ at $\mathrm{pH} 8.0$. for $\mathrm{KCl}$ at 75 and $100 \mathrm{mM}$, semen was diluted $200 \times$ in a plastic tube and sperm motility was estimated at regular intervals. Data points are means; vertical lines represent $+\mathrm{SD}(N=3-5)$.

sampling was $10-12^{\circ} \mathrm{C}$. The captured fish were aged at 3-6 years old by Ohio Department of Natural Resources personnel. Fish were maintained in a holding pen for several hours or overnight before being stripped for semen. Semen was collected into a vial by hand stripping the unanesthetized fish. Semen was collected from 3 males in 1993 and from 15 males in 1994 for this study. Semen was stored on ice before evaluation, and all measurements were finished within $12 \mathrm{~h}$ after gamete 


\section{Year 1994}
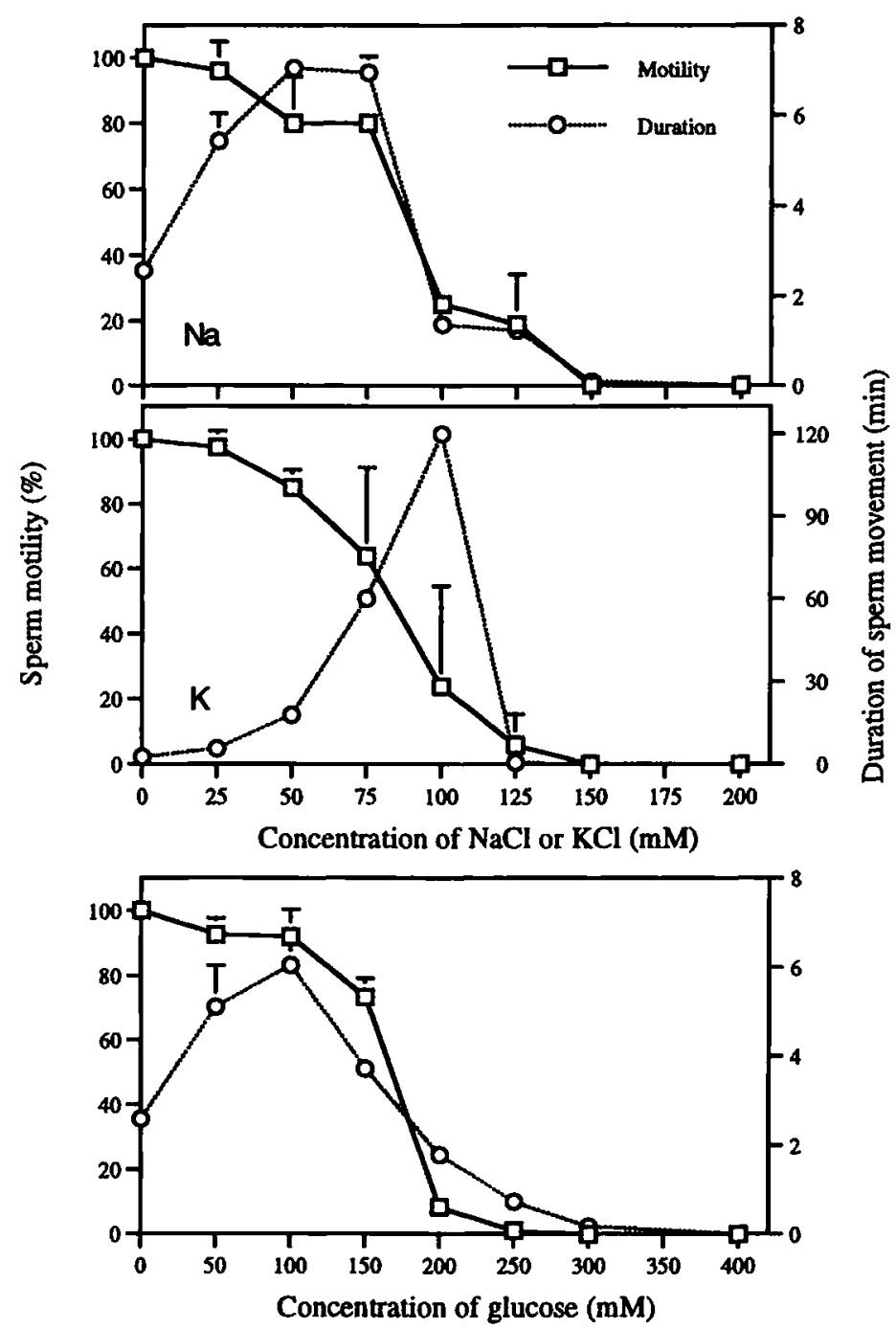

Figure 1.-Extended

collection. During this period, there was no difference in sperm motility after semen was activated in $30 \mathrm{mM}$ tris- $\mathrm{HCl}$ buffer at $\mathrm{pH} 8.0\left(12^{\circ} \mathrm{C}\right)$.

In 1993, semen pooled from 3 males was used with three replicate measurements for each solution. Except as otherwise described, $1 \mu \mathrm{L}$ of semen was mixed with $0.2 \mathrm{~mL}$ of the activation solutions ( $200 \times$ dilution) on a slide and then covered with a cover slip. The activation solutions contained various concentrations of $\mathrm{NaCl}, \mathrm{KCl}$, and glucose in $30 \mathrm{mM}$ tris- $\mathrm{HCl}$ at $\mathrm{pH} 8.0$ to avoid effects from $\mathrm{pH}$ fluctuation. Sperm motility was evaluated by duration of sperm movement and initial percentage of motile sperm. Sperm motility was quantified as quickly as possible with a light microscope at $200 \times$ magnification for initial percentage of motile sperm and rated on an arbitrary scale system of $0-4$ (Suquet et al. 1992). This procedure required 5 to $7 \mathrm{~s}$ from mixing a sperm sample with media to observation of sperm movement. The duration of sperm movement was the time interval from initial mixing to the time that all spermatozoa ceased their forward movement. Because of the long duration of sperm movement in the $\mathrm{KCl}$ so- 


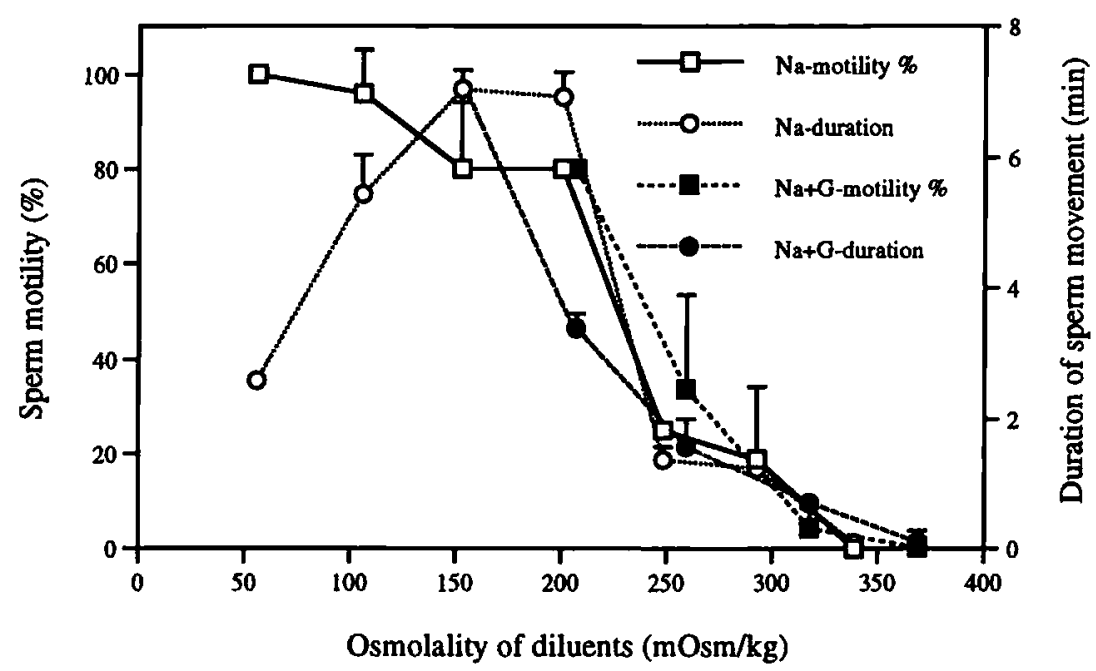

FIGURE 2.-Effects of the combination of sodium and glucose on sperm motility. For activation, $1 \mu \mathrm{L}$ of semen was diluted $200 \times$ with a solution containing equivalent amounts of $\mathrm{NaCl}$ or $\mathrm{NaCl}$ plus glucose in $30 \mathrm{mM}$ tris$\mathrm{HCl}$ at $\mathrm{pH} 8.0$. The tris- $\mathrm{HCl}(30 \mathrm{mM})$ buffer at $\mathrm{pH} 8.0$ had an osmolality of 56 milliosmols $/ \mathrm{kg}$. Data points are means: vertical lines represent $+\mathrm{SD}(N=4)$.

lutions ( 75 and $100 \mathrm{mM} \mathrm{KCl}$ ), semen was activated by $200 \times$ dilution in a plastic tube. Then, $0.2 \mathrm{~mL}$ sperm suspension was transferred to a slide for estimating the percentage of motile sperm at regular intervals after dilution. All measurements were done in a temperature controlled chamber at $12^{\circ} \mathrm{C}$.

In 1994, semen from three to five individual males was used for measurements in each activation solution. Sperm motility was estimated with the same procedures as described above. The percentage of motile sperm was estimated to the nearest $10 \%$. We further investigated the activation solutions containing different concentrations of $\mathrm{KCl}$. $\mathrm{NaCl}, \mathrm{CaCl}_{2}$, and glucose, alone or in combinations, all in $30 \mathrm{mM}$ tris $-\mathrm{HCl}$ at pH 8.0. Effects of potassium and calcium concentrations on sperm motility was also estimated at a fixed osmolality. Potassium ( 10 to $50 \mathrm{mM}$ ) and calcium $(1-30 \mathrm{mM}$ ) solutions were adjusted to the equivalent of a 100 $\mathrm{mM}$ glucose solution (approximately 160 milliosmols [mosmol] $/ \mathrm{kg}$ ), with glucose solutions at appropriate concentrations. Percentage of motile sperm was estimated at regular intervals after activation. The osmolality of activation solutions was measured with a micro osmometer ( $\mu$ OSMETTE, Precision Systems. Inc., Natick. Massachusetts) as described previously (Lin et al. 1996).

Parameters of sperm motility were expressed as arithmetical means and standard deviations. Oneway analysis of variance (ANOVA) and student 1tests were used for comparisons among groups.
The time in which $50 \%$ of the sperm ceased their forward movement was calculated following the method described by Finney (1971).

\section{Results}

Sperm were not activated when the activation solutions had a concentration higher than $125 \mathrm{mM}$ of $\mathrm{NaCl}$ and $\mathrm{KCl}$, or $250 \mathrm{mM}$ glucose in 1993 (Figure 1). The pattern of sperm movement was similar in the two consecutive years, with some exceptions. Muskellunge sperm in 1993 seemed to require lower osmolality to arrest sperm movement than did sperm sampled in 1994. We focused on the results of the 1994 experiments because sperm from individual males was used and in vitro interactions among semen samples was avoided. Sperm were not activated when the activation solutions had a concentration of $200 \mathrm{mM}$ of $\mathrm{NaCl}$ and $\mathrm{KCl}$, or $400 \mathrm{mM}$ of glucose (Figure 1). Only a small portion of sperm was activated at $150 \mathrm{mM}$ of $\mathrm{NaCl}$ and $\mathrm{KCl}$, or $300 \mathrm{mM}$ of glucose. Sperm were fully $(>80 \%)$ activated when the concentration was lower than $50 \mathrm{mM}$ of $\mathrm{NaCl}$ and $\mathrm{KCl}$, or $100 \mathrm{mM}$ glucose. The duration of sperm movement increased to $7 \mathrm{~min}$ and $6 \mathrm{~min}$ at $50 \mathrm{mM} \mathrm{NaCl}$ and $100 \mathrm{mM}$ of glucose, respectively, then gradually decreased as the concentration of solutes decreased. The similarity of both parameters of sperm motility in the activation solutions containing sodium or the equivalent combination of sodium and glucose $(30 \mathrm{mM}$ tris- $\mathrm{HCl}$ buffer had an 


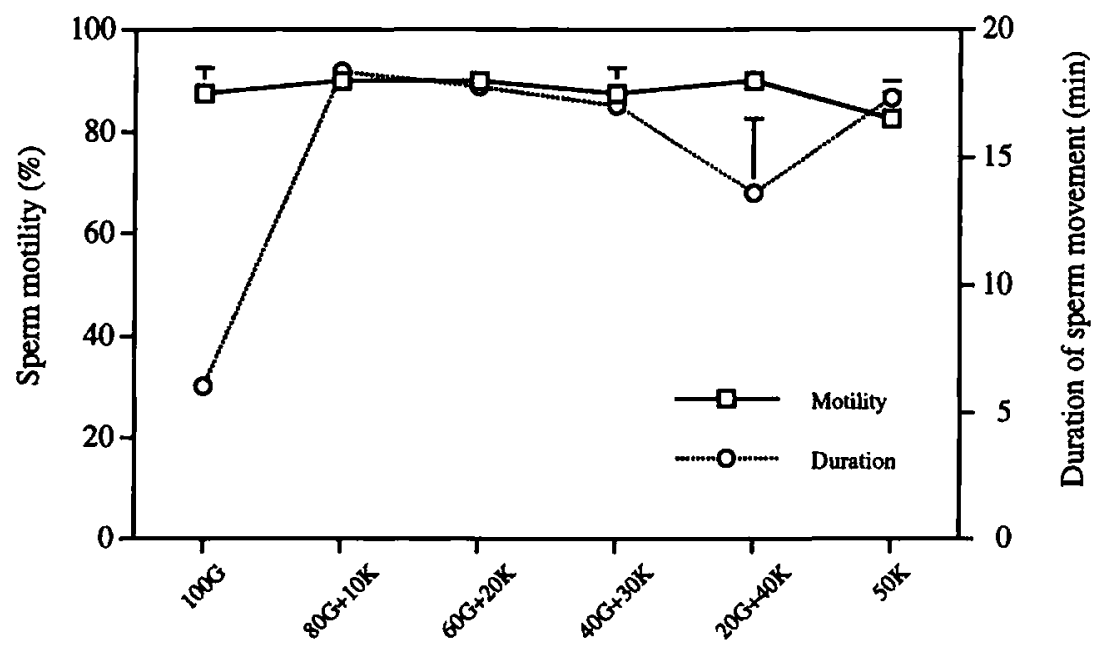

Diluents (mM)

FIGURE 3.-Effects of potassium concentration on muskellunge sperm motility at a fixed osmolality. Osmolality of diluents was adjusted by glucose to the equivalent of $100 \mathrm{mM}$ glucose in $30 \mathrm{mM}$ tris- $\mathrm{HCl}$ at pH 8.0 (approximately 160 milliosmols $/ \mathrm{kg})$. Data points are means; vertical lines represent $+\mathrm{SD}(N=3)$.

osmolality of $56 \mathrm{mosmol} / \mathrm{kg}$ ) indicated that the effects of sodium on sperm motility were primarily osmotic (Figure 2).

The observed initial percentage of motile sperm in potassium solutions was similar to those in sodium and glucose solutions. However, sperm had a prolonged duration of movement in $\mathrm{KCl}$ solutions, up to $120 \mathrm{~min}$ at $100 \mathrm{mM} \mathrm{KCl}$ (Figure 1). The effect of potassium was also studied at a fixed osmolality equivalent to a $100 \mathrm{mM}$ glucose solution (160 mosmol $/ \mathrm{kg}$ ). Potassium significantly $(P<0.001)$ increased the duration of sperm movement regardless of its concentration from 10 to 50 $\mathrm{mM}(18 \mathrm{~min})$ compared with $100 \mathrm{mM}$ glucose alone (6 min; Figure 3 ).

Calcium concentration as low as $3 \mathrm{mM}$ significantly $(P<0.001)$ inhibited sperm motility (Figure 4). Initial percentage of motile sperm de-

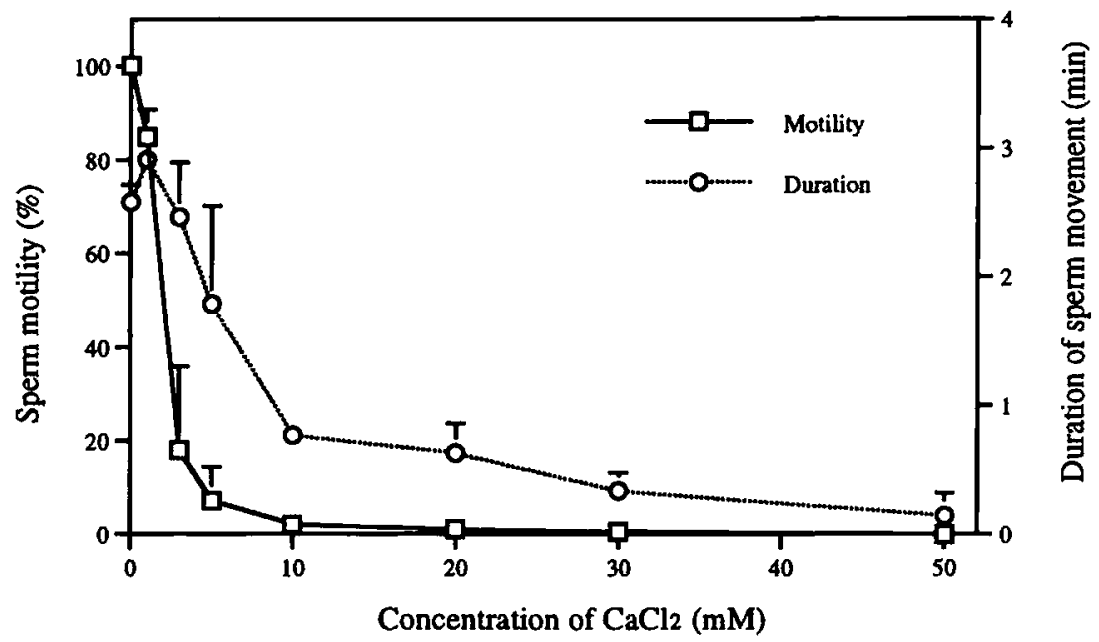

FIGURE 4.-Effects of calcium concentration on sperm motility. Semen was diluted $(200 \times)$ in activation solutions containing various calcium concentrations in $30 \mathrm{mM}$ tris $-\mathrm{HCl}$ at $\mathrm{pH}$ 8.0. Data points are means: vertical lines represent $+\mathrm{SD}(N=3)$. 


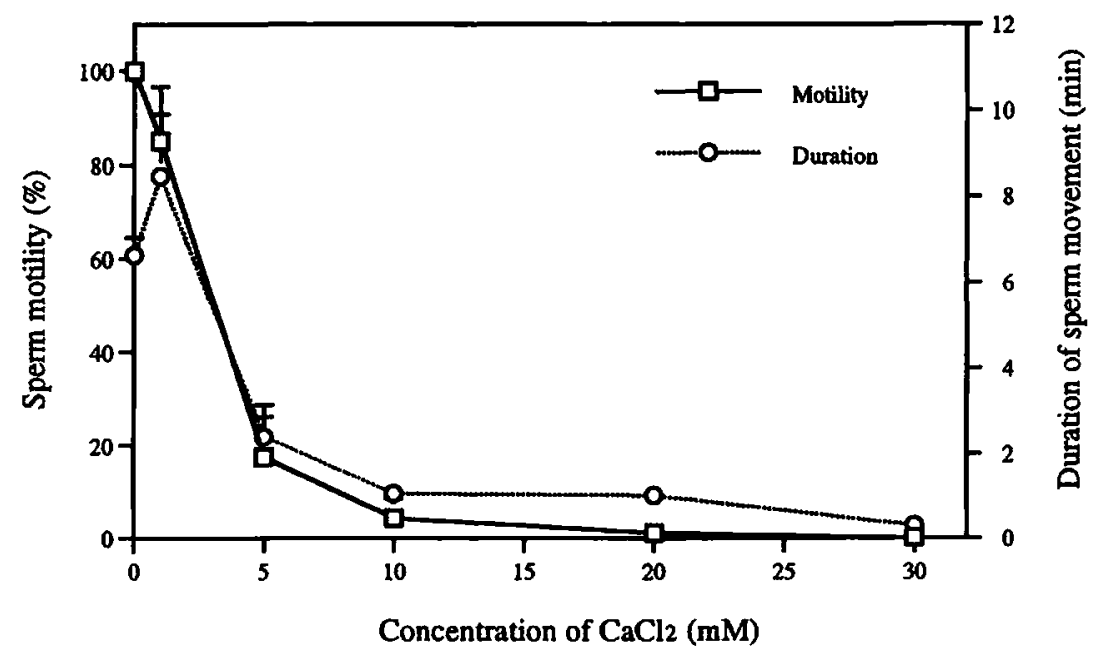

Figure 5.-Effects of calcium concentration on muskellunge sperm motility at a fixed osmolality. Osmolality of diluents was adjusted by glucose to the equivalent of $100 \mathrm{mM}$ glucose in $30 \mathrm{mM}$ (ris- $\mathrm{HCl}$ at pH 8.0 (160 milliosmols $/ \mathrm{kg})$. Data points are means; vertical lines represent $+\mathrm{SD}(N=3)$.

creased from $80 \%$ to $20 \%$ when calcium concentration was increased from I to $3 \mathrm{mM}$. At $10 \mathrm{mM}$, calcium almost completely inhibited the sperm motility ( $2 \%$ motile sperm). However, a few spermatozoa were still activated at $50 \mathrm{mM}$ calcium. The duration of sperm movement also decreased with increasing calcium concentration. Similar in hibitory patterns were found in the effects of calcium concentrations at fixed osmolality ( 160 mos$\mathrm{mol} / \mathrm{kg}$ ) adjusted by glucose (Figure 5 ). Calcium caused clumping of the sperm and decreased the swimming speed.

Percentage of motile sperm decreased over time (Figure 6). Most of the sperm ceased their forward movement within $2 \mathrm{~min}$, but a few spermatozoa swam for a few more minutes in tris buffer ( 30 $\mathrm{mM})$ and sodium $(50 \mathrm{mM})$ media. The decline in percentage of motile sperm was less sharply pronounced in the potassium solution $(50 \mathrm{mM})$; at 2 min after activation, $20 \%$ motile sperm were ob-

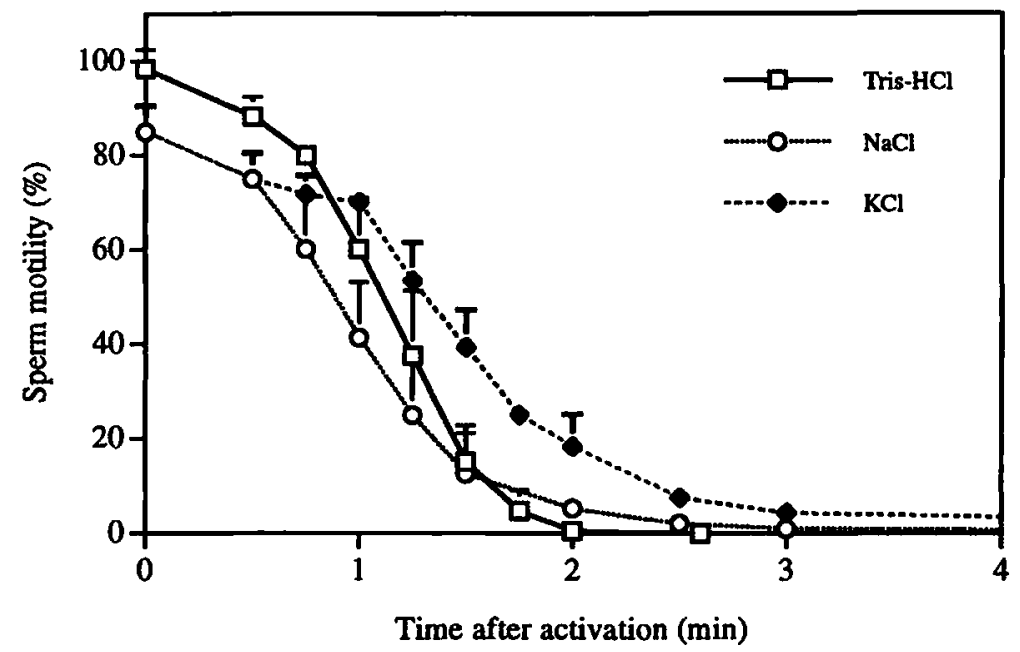

FIGURE 6.-Change in percentage of motile sperm over time after activation. Semen was diluted $(200 \times)$ in activation solutions of tris- $\mathrm{HCl}, \mathrm{NaCl}$, or $\mathrm{KCl}(50 \mathrm{mM})$. Percentage of motile sperm was estimated at regular intervals after activation. Tris $=30 \mathrm{mM}$ tris- $\mathrm{HCl}$ at $\mathrm{pH} 8.0, \mathrm{NaCl}=50 \mathrm{mM} \mathrm{NaCl}$ in $30 \mathrm{mM}$ tris- $\mathrm{HCl}$ at $\mathrm{pH} 8.0$, $\mathrm{KCl}=50 \mathrm{mM} \mathrm{KCl}$ in $30 \mathrm{mM}$ tris- $\mathrm{HCl}$ at pH 8.0. Data points are means; vertical lines represent $+\operatorname{SD}(N=4)$. 
served. The average time that $50 \%$ sperm ceased their forward movement in sodium, tris, and potassium media was 50,64 , and $74 \mathrm{~s}$, respectively. However, there was no significant difference among these three groups.

\section{Discussion}

Spermatozoa of muskellunge were immotile in a solution containing either an electrolyte $(\mathrm{NaCl}$ or $\mathrm{KCl}$ ) or nonelectrolyte (glucose) at a high concentration. A small number of sperm became motile when the diluents had the osmolality of 340 mosmol/kg ( $150 \mathrm{mM} \mathrm{NaCl}$ and $\mathrm{KCl}$, or $300 \mathrm{mM}$ glucose), higher than that of the seminal plasma (290 mosmol $/ \mathrm{kg}$, Lin et al. 1996). Sperm motility initiated in isotonic to hypertonic media in northern pike, channel catfish lctalurus punctatus, and salmonids has been reported (reviewed by Stoss 1983). Strussmann et al. (1994) reported that sperm of the freshwater fish pejerrey Odontesthes bonariensis became motile when diluted with nonelectrolyte solutions up to $388 \mathrm{mosmol} / \mathrm{kg}$ and electrolyte solutions up to $551 \mathrm{mosmol} / \mathrm{kg}$, while the osmolality of seminal plasma was $331 \mathrm{mosmol} /$ $\mathrm{kg}$. The results from 1993 indicated that activation solutions containing $125 \mathrm{mM} \mathrm{NaCl}$ and $\mathrm{KCl}$, or $300 \mathrm{mM}$ glucose inhibited sperm motility (Figure 1). Unfortunately, at that time we did not have the equipment to measure the osmolality of the diluents in order to make direct comparisons. The similar patterns of both parameters of sperm motility was found in sodium and glucose solutions, alone or in combinations, in muskellunge, as was the case in freshwater cyprinids (Morisawa et al. 1983b). This similarity suggests that the motility of muskellunge sperm is regulated by the changes of the osmolality in the environment. The duration of sperm movement in muskellunge was up to 6$7 \mathrm{~min}$ in a solution of glucose $(100 \mathrm{mM})$ or $\mathrm{NaCl}$ $(50 \mathrm{mM}$ ). During the 1993 experiments, longer duration of sperm movement was observed, perhaps because of variation between seasons and duration of sperm movement of pooled sperm represented the individual with longest motility. The variability between individual males is the major reason we chose to use individual males during the 1994 season. Results for the duration of sperm movement in muskellunge are comparable to those observed by Billard (1978) in northern pike (3-5 $\mathrm{min}$ in $0.7 \%$ physiological solution) and by Morisawa et al. (1983b) in cyprinids (6 min in 100 mosmol $/ \mathrm{kg}$ of $\mathrm{NaCl}$ ). However, Duplinsky (1982) reported a movement duration of $67 \mathrm{~s}$ for northern pike sperm in tap water buffered to $\mathrm{pH} 7.9$. How- ever, different observation methods and conditions of sperm activation, including temperature and diluent, limit direct comparison of results.

Morisawa et al. (1983b) reported that potassium maintained motility and increased the swimming speed of cyprinid fish spermatozoa. We found that muskellunge sperm also have a prolonged duration of movement in potassium solutions. The duration of sperm movement increased from $6 \mathrm{~min}$ in 100 $\mathrm{mM}$ glucose solution to about $18 \mathrm{~min}$ in 10 to 50 $\mathrm{mM} \mathrm{KCl}$, adjusted by glucose to the equivalent of $100 \mathrm{mM}$ glucose in osmolality (Figure 3). Some motile sperm appeared up to $2 \mathrm{~h}$ after activation in $100 \mathrm{mM} \mathrm{KCl}$. Such a long duration of movement is rare in freshwater fish. This extended motility might be caused by reactivation of sperm (Christen et al. 1987) or gradual activation of "subpopulations" of sperm cells during observations. We noticed that sperm could be reactivated with $30 \mathrm{mM}$ tris- $\mathrm{HCl}$ buffer 10 min after being activated with a $25 \mathrm{mM} \mathrm{KCl}$ solution (our unpublished data). Thus, muskellunge sperm potentially provides a valuable model for the investigation of sperm reactivation and prolonged movement generated by potassium influx. Sperm of rainbow troul Ohcorhynchus mykiss is activated by a decrease in external potassium concentration below $3 \mathrm{mM}$ (Morisawa and Suzuki 1980). This contrast represents a major difference between cyprinid sperm and muskellunge sperm.

External calcium has been shown to antagonize the potassium inhibition of motility in rainbow trout (Baynes et al. 1981: Tanimoto and Morisawa 1988). Calcium at $10 \mathrm{mM}$ maintained the swimming speed and increased the duration of movement in rainbow trout sperm (Perchec et al. 1993). Conflicting interpretations have resulted from intensive investigation of the role of calcium in rainbow trout sperm activation. By using $\mathrm{Ca}^{2+}$-channel blockers, a flux of external $\mathrm{Ca}^{2+}$ into the cell rather than a mobilization of internal $\mathrm{Ca}^{2+}$ stores was demonstrated to be required to activate sperm motility in rainbow trout (Tanimoto and Morisawa 1988; Cosson et al. 1989). The finding that rainbow trout sperm can be activated in the absence of extracellular $\mathrm{Ca}^{2+}$ suggests that no influx of extracellular $\mathrm{Ca}^{2+}$ is required for activation (Boitano and Omoto 1992). Okuno and Morisawa (1989) have also shown an inhibitory effect of relatively low calcium concentration on reactivation of demembranated rainbow trout sperm. We found that $3 \mathrm{mM}$ calcium had an inhibitory effect on sperm motility in muskellunge. Semen diluted in calcium solutions did not disperse well and 
sperm tended to form clumps. A few sperm activated in a solution of high calcium concentration showed slow forward movement that ceased within $30 \mathrm{~s}$. There is no report, to our knowledge, on the mechanism of calcium fluxes in sperm where motility is regulated by osmolality.

\section{Acknowledgments}

We thank John D. Harder of the Department of Zoology and Jennifer Tomsen of the School of Natural Resources, The Ohio State University, for their critical reading of this manuscript. Thanks are due to Andrzej Ciereszko for his valuable discussions. We appreciate helpful cooperation in sampling gametes and providing fish information from Richard Day, Frank Kapler, and Bruce Bartens of the Ohio Department of Natural Resources. This work was funded by Piketon Research and Extension Center seed grant program and the Federal Aid in Sport Fish Restoration (project F-69P, Fish Management in Ohio), adminstered jointly by the United States Fish and Wildlife Service and the Ohio Division of Wildlife. Salaries were partly provided by the state and federal funds appropriated to the Ohio Agriculture Research and Development Center (OARDC). This is OARDC manuscript $48 / 95$.

\section{References}

Baynes, S. M., A. P. Scott, and A. P. Dawson. 1981. Rainbow trout. Salmo gairdnierii Richardson, spermatozoa: effects of cations and $\mathrm{pH}$ on motility. Journal of Fish Biology 19:259-267.

Billard, R. 1978. Changes in structure and fertilizing ability of marine and freshwater fish spermatozoa diluted in media of various salinities. Aquaculture 14:187-198.

Boitano, S., and C. K. Omoto. 1992. Trout sperm swimming patterns and roles of intracellular $\mathrm{Ca}^{++}$. Cell Motility and the Cytoskeleton 21:74-82.

Christen, R., J.-L. Gatti, and R. Billard. 1987. Trout sperm motility: the transient movement of trout sperm is related to changes in the concentration of ATP following the activation of the flagellar movement. European Journal of Biochemistry 166:667$67 !$.

Cosson, M. P., R. Billard, and L. Letellier. 1989. Rise of internal $\mathrm{Ca}^{2+}$ accompanies the initiation of trout sperm motility. Cell Motility and the Cytoskeleton 14:424-434.

Duplinsky, P. D. 1982. Sperm motility of northern pike and chain pickerel at various $\mathrm{pH}$ values. Transactions of the American Fisheries Society 111:768771.
Finney, D. J. 1971. Probit analysis, 3rd edition. Cambridge University Press.

Galat, D. L. 1973. Normal embryonic development of the muskellunge (Esox masquinongy). Transactions of the American Fisheries Society 102:384-391.

Hasler, A. D., R. K. Meyer, and H. M. Field. 1940. The use of hormones for the conservation of muskellunge, Esox masquinongy imaculatus Garrard. Copeia 940:43-46.

Lin, F., L. Liu, and K. Dabrowski. 1996. Characteristics of muskellunge spermatozoa I: Ultrastructure of spermatozoa and biochemistry composition of semen. Transactions of the American Fisheries Society 125 :

Moore, A. A. 1991. Refrigerated storage and cryopreservation of walleye and muskellunge semen. Iowa Department of Natural Resources, Technical Bulletin 4, Des Moines.

Morisawa, M., and K. Suzuki. 1980. Osmolality and potassium ion: their roles in initiation of sperm motility in teleost. Science 210:1145-1147.

Morisawa, M., K. Suzuki, and S. Morisawa. 1983a. Effects of potassium and osmolality on spermatozoa motility of salmonid fishes. Journal of Experimental Biology 107:105-113.

Morisawa, M., K. Suzuki, H. Shimizu, S. Morisawa, and K. Yasuda. 1983b. Effects of osmolality and potassium on motility of spermatozoa from freshwater cyprinid fishes. Journal of Experimental Biology 107:95-103.

Okuno, M., and M. Morisawa. 1989. Effects of calcium on motility of rainbow trout sperm flagella. Cell Motility and the Cytoskeleton 14:194-200.

Perchec. P. G., J. Cosson. F. Andre, and R. Billard. 1993. La motilite des spermatozoides de truite (Oncorhynchus mykiss) et de carpe (Cyprinus carpio). Journal of Applied Ichthyology 9(3-4):129-149.

Redondo-Muller, C., M.-P. Cosson, J. Cosson, and R. Billard. 199I. In vitro maturation of the potential for movement of carp spermatozoa. Molecular Reproduction and Development 29:259-270.

Stoss, J. 1983. Fish gamete preservation and spermatozoa physiology. Pages 305-350 in W. S. Hoar, D. J. Randall, and E. M. Donaldson, editors. Fish Physiology: reproduction, volume 9. part B. Academic Press, New York.

Strussmann, C. A., P. Renard. H. Ling, and F. Takashima 1994. Motility of pejerrey Odontesthes bonariensis spermatozoa. Fisheries Science 60(1):9-13.

Suquet, M., H. M. Omnes, Y. Normant, and C. Fauvel. 1992. Assessment of sperm concentration and motility in turbot (Scophthalmus maximus). Aquaculture 101:177-185.

Tanimoto, S., and M. Morisawa. 1988. Roles for potassium and calcium channels in the initiation of sperm motility in rainbow trout. Development. Growth and Differentiation 30:117-124.

Received March 20. 1995 Accepted September 7, 1995 